\title{
New Brominated and Halogen-less Derivatives and Structure-activity Relationship of Azaphilones Inhibiting gp120-CD4 Binding
}

\author{
Keilchi Matsuzaki, Harumi Tahara, Junji InOKoshi and Haruo Tanaka* \\ School of Pharmaceutical Sciences, Kitasato University \\ Rokuro Masuma and SATOShi ŌMURA* \\ Research Center for Biological Function, The Kitasato Institute, \\ Minato-ku, Tokyo 108-8641, Japan \\ (Received for publication June 25, 1998)
}

\begin{abstract}
Novel brominated and halogen-less azaphilone (oxoisochromane) derivatives, 5-bromoochrephilone and dechloroisochromophilone IV, and known derivatives, dechloroisochromophilone III and isorotiorin, were isolated from the culture broth of a producing organism of isochromophilones I and II (azaphilones inhibiting gp120-CD4 binding), Penicillium multicolor FO-2338, fermented in a medium containing potassium bromide. Nineteen azaphilone-related compounds isolated from the above strain and from other fungi were tested for the inhibition of gp 120-CD4 binding and the structure-activity relationship is discussed. Consequently, 5-bromoochrephilone is the strongest inhibitor $\left(\mathrm{IC}_{50}, 2.5 \mu \mathrm{M}\right)$. A halogen atom at $\mathrm{C}-5$, a proton at $\mathrm{C}-8$ and a diene structure in $\mathrm{C}-3$ side chain of 6-oxoisochromane ring are necessary for gp120-CD4 binding.
\end{abstract}

Fungal metabolites having an oxoisochromane ring system, which are called "azaphilones" after high affinity to ammonia), have been found to possess various bioactivities. In the course of screening of microbial metabolites for the inhibition of gp120-CD4 binding, we discovered the inhibitors isochromophilones I (1) and II (2) having a 6-oxoisochromane ring, which were isolated from a culture broth of Penicillium multicolor FO$2338^{2 \sim 4)}$ together with the known azaphilones ochrephilone (3) $)^{5)}$, sclerotiorin $(4)^{6)}$ and rubrorotiorin $(5)^{6}$. 1, 5-chloro derivative of ochrephilone, exhibited a strong inhibitory activity against gp120-CD4 binding but 3 showed no inhibition. These results suggested that a chlorine atom at C-5 of $\mathbf{1}$ was very important for the inhibition of gp120-CD4 binding. Thus, we attempted the preparation of brominated derivatives by a fermentative process. When the isochromophilone producer P. multicolor FO-2338 was fermented in a production medium containing $3.0 \%$ potassium bromide, a new brominated derivative and several other azaphilonerelated compounds were produced in the culture broth. In this paper, we wish to report the isolation and the structures of a 5-bromo derivative and other azaphilonerelated compounds, and the structure-activity relation- ship among azaphilone-related compounds including those isolated from other fungi for the inhibition of gp120-CD4 binding.

\section{Fermentation and Isolation}

The production of azaphilones by $P$. multicolor FO-2338 was carried out using Erlenmeyer flasks and a jar fermentor containing a production medium supplemented with $3.0 \%$ potassium bromide as described in the Experimental section.

The isolation procedures for azaphilone-related compounds are summarized in Fig. 1. 3, 6, 7 and 10 were isolated from the cultured broth obtained using Erlenmeyer flasks. 8 and 9 in addition to 3 and 10 were isolated from the cultured broth using a jar fermentor.

\section{Structure Elucidation}

6 was obtained as a yellow powder. The molecular formula was determined to be $\mathrm{C}_{19} \mathrm{H}_{26} \mathrm{O}_{4}$ based on its HR-FAB-MS. The ${ }^{1} \mathrm{H}$ - and ${ }^{13} \mathrm{C}-\mathrm{NMR}$ spectra indicated the presence of a 3,5-dimethyl-1,3-heptadiene moiety which is also contained in isochromophilones I (1) and II (2). In the ${ }^{1} \mathrm{H}-\mathrm{NMR}$, two olefin signals at $\delta 5.65$ (s) and $5.72(\mathrm{~s})$, a methyl signal at $\delta 1.48(\mathrm{~s})$, oxymethylene 
Fig. 1. Isolation procedures for azaphilones.
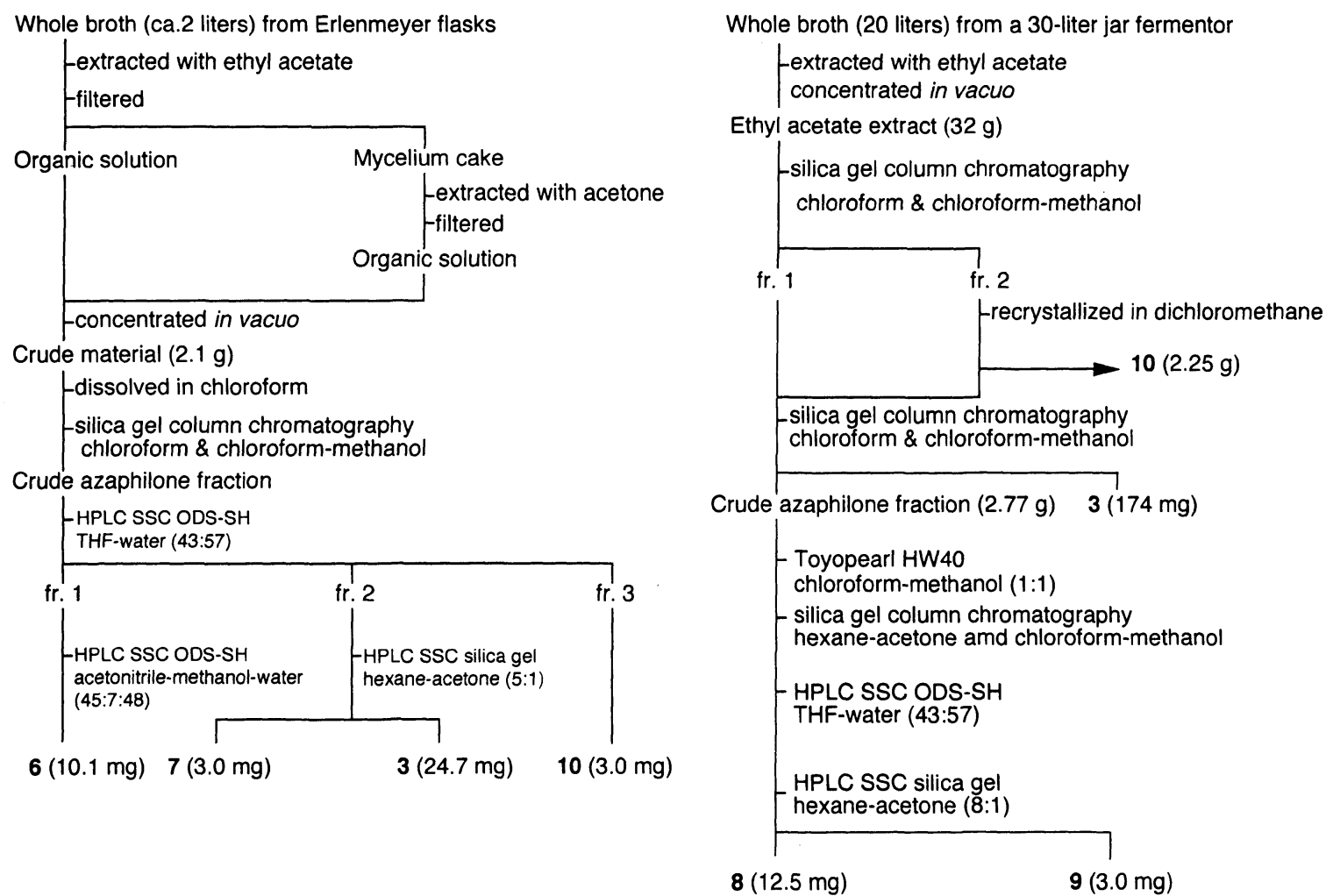

Fig. 2. The structures of azaphilones and related compounds obtained by fermentation in the presence of potassium bromide.<smiles>CC[C@H](C)/C=C(C)/C=C/C1=CC2=CC(=O)[C@@](C)(O)[C@H](O)[C@]2(C)CO1</smiles>

Dechloroisochromophilone III (6): $R=H$ 8-Acetyldechloroisochromophilone III (7): $R=A c$<smiles>CC[C@H](C)/C=C(C)/C=C/C1=CC2=CC(=O)[C@@]3(C)OC(=O)C(C(C)=O)=C3C2=CO1</smiles>

signals at $\delta 3.78(\mathrm{dd})$ and $4.82(\mathrm{dd})$ and methine signals at $\delta 3.00(\mathrm{~m})$ and $3.45(\mathrm{~d})$ were observed in addition to the signals of 3,5-dimethyl-1,3-heptadiene. From the above data and the 2D NMR study, 6 was identified to be dechloroisochromophilone III $^{7}$.

7 was also obtained as a yellow powder. The molecular

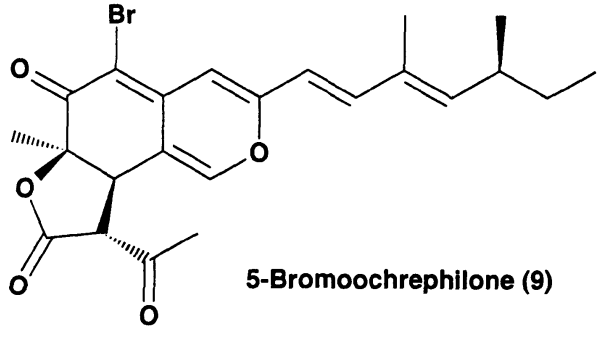<smiles>CC[C@H](C)/C=C(C)/C=C/C(=O)Cc1cc(O)c(C)c(O)c1C=O</smiles>

2,4-Dihyroxy-6-(5,7-dimethyl-2-oxo-trans-3-trans5-nonadinenyl)-3-methylbenzaldehydede (10)

formula was determined to be $\mathrm{C}_{19} \mathrm{H}_{26} \mathrm{O}_{4}$ based on its HR-FAB-MS. The molecular weight was forty-two mass units larger than that of 6 . In the IR spectrum, the absorptions at 1740 and $1630 \mathrm{~cm}^{-1}$ indicated the presence of a carbonyl group and an $\alpha, \beta$-unsaturated carbonyl group, respectively. The ${ }^{1} \mathrm{H}-\mathrm{NMR}$ of 7 was 
Table $1 .{ }^{13} \mathrm{C}$ - and ${ }^{1} \mathrm{H}$-NMR spectral data of 6 and 7.

\begin{tabular}{|c|c|c|c|c|c|}
\hline \multirow[b]{2}{*}{ Number } & \multicolumn{3}{|c|}{6} & \multicolumn{2}{|l|}{7} \\
\hline & $\delta C$ & & & $\delta \mathrm{H}$ & \\
\hline 1 & $69.2 \mathrm{t}$ & $\begin{array}{l}3.78 \\
4.82\end{array}$ & $\begin{array}{l}1 \mathrm{H} \text { dd } J=13.5,10.9 \mathrm{~Hz} \\
1 \mathrm{H} \text { dd } J=10.9,5.6 \mathrm{~Hz}\end{array}$ & $\begin{array}{l}3.80 \\
4.37\end{array}$ & $1 \mathrm{H}$ dd $J=13.5,10.9 \mathrm{~Hz}$ \\
\hline 3 & $162.3 \mathrm{~s}$ & & & & \\
\hline 4 & $104.6 \mathrm{~d}$ & 5.65 & $1 \mathrm{H} \mathrm{s}$ & 5.67 & $1 \mathrm{H} \mathrm{s}$ \\
\hline $4 a$ & $152.5 \mathrm{~s}$ & & & & \\
\hline 5 & $115.7 \mathrm{~d}$ & 5.72 & $1 \mathrm{H} \mathrm{d} J=1.6 \mathrm{~Hz}$ & 5.77 & $1 \mathrm{H} \mathrm{d} J=2.0 \mathrm{~Hz}$ \\
\hline 6 & $196.8 \mathrm{~s}$ & & & & \\
\hline 7 & $74.8 \mathrm{~s}$ & & & & \\
\hline 8 & $74.6 \mathrm{~d}$ & 3.45 & $1 \mathrm{H} \mathrm{d} J=9.2 \mathrm{~Hz}$ & 5.00 & $1 \mathrm{H} \mathrm{d} J=9.6 \mathrm{~Hz}$ \\
\hline $8 a$ & $37.1 \mathrm{~d}$ & 3.00 & $1 \mathrm{H} \mathrm{m}$ & 3.35 & $1 \mathrm{H} \mathrm{m}$ \\
\hline 9 & $119.4 \mathrm{~d}$ & 5.89 & $1 \mathrm{H} \mathrm{d} J=15.5 \mathrm{~Hz}$ & 5.89 & $1 \mathrm{H} \mathrm{d} J=15.5 \mathrm{~Hz}$ \\
\hline 10 & $141.0 \mathrm{~d}$ & 6.94 & $1 \mathrm{H} \mathrm{d} J=15.5 \mathrm{~Hz}$ & 6.89 & $1 \mathrm{H} \mathrm{d} J=15.5 \mathrm{~Hz}$ \\
\hline 11 & $132.5 \mathrm{~s}$ & & & & \\
\hline 12 & $146.6 \mathrm{~d}$ & 5.57 & $1 \mathrm{H} \mathrm{d} J=9.5 \mathrm{~Hz}$ & 5.55 & $1 \mathrm{H} \mathrm{d} J=9.6 \mathrm{~Hz}$ \\
\hline 13 & $35.3 \mathrm{~d}$ & 2.24 & $1 \mathrm{H} \mathrm{m}$ & 2.45 & $1 \mathrm{H} \mathrm{m}$ \\
\hline 14 & $30.6 \mathrm{t}$ & 1.33 & $2 \mathrm{H} \mathrm{m}$ & 1.33 & $2 \mathrm{H} \mathrm{m}$ \\
\hline 15 & $12.3 \mathrm{q}$ & 0.82 & $3 \mathrm{H} \mathrm{t} J=7.5 \mathrm{~Hz}$ & 0.84 & $3 \mathrm{H}$ t $J=7.5 \mathrm{~Hz}$ \\
\hline 7- $\mathrm{CH}_{3}$ & $21.0 \mathrm{q}$ & 1.48 & $3 \mathrm{H} \mathrm{s}$ & 1.36 & $3 \mathrm{H} \mathrm{s}$ \\
\hline $11-\mathrm{CH}_{3}$ & $12.8 \mathrm{q}$ & 1.78 & $3 \mathrm{H} \mathrm{d} J=1.0 \mathrm{~Hz}$ & 1.78 & $3 \mathrm{H} \mathrm{d} J=1.0 \mathrm{~Hz}$ \\
\hline $13-\mathrm{CH}_{3}$ & $20.7 q$ & 0.98 & $3 \mathrm{H} \mathrm{d} J=6.9 \mathrm{~Hz}$ & 0.97 & $3 \mathrm{H} \mathrm{d} J=6.7 \mathrm{~Hz}$ \\
\hline $\mathrm{COCH}_{3}$ & & & & 2.22 & $3 \mathrm{H} \mathrm{s}$ \\
\hline
\end{tabular}

$\delta=$ ppm in $\mathrm{CDCl}_{3}$.

Table 2. ${ }^{13} \mathrm{C}$ - and ${ }^{1} \mathrm{H}-\mathrm{NMR}$ spectral data of 8 and 9.

\begin{tabular}{|c|c|c|c|c|c|c|}
\hline \multirow[b]{2}{*}{ Number } & \multicolumn{4}{|c|}{8} & \multicolumn{2}{|c|}{9} \\
\hline & $\delta_{C}$ & & & $\delta_{H}$ & & \\
\hline 1 & 153.1 & $\mathrm{~d}$ & 8.84 & $1 \mathrm{H} \mathrm{s}$ & 7.42 & $1 \mathrm{H} \mathrm{s}$ \\
\hline 2 & 156.3 & s & & & & \\
\hline 4 & 108.2 & d & 6.16 & $1 \mathrm{H} \mathrm{s}$ & 6.56 & $1 \mathrm{Hs}$ \\
\hline $4 a$ & 123.1 & s & & & & \\
\hline 5 & 105.3 & d & 6.34 & $1 \mathrm{H} \mathrm{s}$ & & \\
\hline 6 & 189.9 & s & & & & \\
\hline 7 & 87.5 & s & & & & \\
\hline 8 & 165.6 & s & & & 3.83 & $1 \mathrm{H} \mathrm{d} \mathrm{J}=12.0 \mathrm{~Hz}$ \\
\hline $8 \mathrm{a}$ & 110.7 & s & & & & \\
\hline 9 & 115.4 & d & 5.97 & $1 \mathrm{H} \mathrm{d} J=15.8 \mathrm{~Hz}$ & 6.05 & $1 \mathrm{H} \mathrm{d} J=15.8 \mathrm{~Hz}$ \\
\hline 10 & 144.1 & d & 7.04 & $1 \mathrm{H} \mathrm{d} J=15.8 \mathrm{~Hz}$ & 7.04 & $1 \mathrm{H} \mathrm{d} \mathrm{J}=15.8 \mathrm{~Hz}$ \\
\hline 11 & 131.8 & s & & & & \\
\hline 12 & 148.3 & d & 5.67 & $1 \mathrm{H} \mathrm{d} J=9.9 \mathrm{~Hz}$ & 5.68 & $1 \mathrm{H} \mathrm{d} J=9.9 \mathrm{~Hz}$ \\
\hline 13 & 35.5 & d & 2.48 & $1 \mathrm{H} \mathrm{m}$ & 2.45 & $1 \mathrm{H} \mathrm{m}$ \\
\hline 14 & 30.0 & $\mathrm{t}$ & 1.35 & $2 \mathrm{H} \mathrm{m}$ & 1.35 & $2 \mathrm{H} \mathrm{m}$ \\
\hline 15 & 11.9 & $q$ & 0.85 & $3 \mathrm{H} \mathrm{t} J=7.5 \mathrm{~Hz}$ & 0.85 & $3 \mathrm{H} \mathrm{t} J=7.5 \mathrm{~Hz}$ \\
\hline $7-\mathrm{CH}_{3}$ & 26.4 & $\mathrm{q}$ & 1.69 & $3 \mathrm{H} \mathrm{s}$ & 1.62 & $3 \mathrm{H} \mathrm{s}$ \\
\hline $11-\mathrm{CH}_{3}$ & 12.4 & $q$ & 1.81 & $3 \mathrm{H} \mathrm{s}$ & 1.83 & $3 \mathrm{H} \mathrm{s}$ \\
\hline $13-\mathrm{CH}_{3}$ & 20.1 & $q$ & 1.00 & $3 \mathrm{H} \mathrm{d} J=6.7 \mathrm{~Hz}$ & 0.98 & $3 \mathrm{H} \mathrm{d} J=8.6 \mathrm{~Hz}$ \\
\hline $2^{\prime}$ & 168.3 & s & & & & \\
\hline $3^{\prime}$ & 142.3 & $\mathrm{~S}$ & & & 3.80 & $1 \mathrm{H} \mathrm{d} \mathrm{J}=12.2 \mathrm{~Hz}$ \\
\hline $4^{\prime}$ & 194.4 & s & & & & \\
\hline $5^{\prime}$ & 30.0 & $q$ & 2.59 & $3 \mathrm{H} \mathrm{s}$ & 2.44 & $3 \mathrm{H} \mathrm{s}$ \\
\hline
\end{tabular}

$\delta=$ ppm in $\mathrm{CDCl}_{3}$.

very similar to that of 6 (Table 1). However, a methyl signal appeared at $\delta 2.22$, and an oxymethylene signal (8-H) was shifted downfield to $\delta 5.00$ by acetylation. From the above data, the structure of 7 was determined to be the new compound dechloroisochromophilone IV.

$\mathbf{8}$ was obtained as a red powder. The molecular formula was determined to be $\mathrm{C}_{23} \mathrm{H}_{24} \mathrm{O}_{5}$ by HR-FAB-MS, and the molecular weight (380) was two mass units less than that of 3. The ${ }^{1} \mathrm{H}$ - and ${ }^{13} \mathrm{C}$-NMR spectra of 8 were very similar to those of $3^{4}$. However, two methine proton signals (8-, $3^{\prime}-H$ in 3 ) were not observed. In the ${ }^{13} \mathrm{C}-\mathrm{NMR}$ spectrum, olefin carbon signals were observed at $\delta 110.7$ 
and 142.3 instead of the two methine carbon signals of 3. From these results, the structure of $\mathbf{8}$ was identified to be isorotiorin ${ }^{8}$.

9 was obtained as a yellow powder. The molecular ion peaks at $m / z 461$ and $463(1: 1)$ in the EI-MS suggested that 9 possessed a bromine atom. The molecular formula of 9 was determined to be $\mathrm{C}_{23} \mathrm{H}_{25} \mathrm{O}_{5} \mathrm{Br}$ by HR-EI-MS. The UV and IR spectra of 9 were very similar to those of $\mathbf{1}^{2,4)}$.

The ${ }^{1} \mathrm{H}-\mathrm{NMR}$ data were also closely similar to those of 8 (Table 2) and identical with those of $\mathbf{1}^{4)}$. These data indicated that 9 has a 6-oxoisochromane skeleton as does 1 and that a bromine atom should be attached to C-5. From these results, the structure of 9 was determined to be the new compound 5-bromoochrephilone.

10 was obtained as colorless needles. The molecular formula was determined to be $\mathrm{C}_{19} \mathrm{H}_{24} \mathrm{O}_{4}$ from HR-FAB-MS. In the IR spectrum, the absorptions at 1680 and $1625 \mathrm{~cm}^{-1}$ indicated the presence of two carbonyl groups. In the ${ }^{1} \mathrm{H}-\mathrm{NMR}$, the signals of four methyls, two methylenes, a methine, four olefin protons, one aldehyde proton and two phenolic protons were observed. The ${ }^{1} \mathrm{H}-$ and ${ }^{13} \mathrm{C}-\mathrm{NMR}$ and ${ }^{1} \mathrm{H}^{-1} \mathrm{H}$ COSY data revealed the presence of a 3,5-dimethyl-1,3heptadiene residue. The remainder of the structure was established by HMBC correlations as shown in Fig. 3. The 3,5-dimethyl-1,3-heptadiene residue was attached to a ketone carbonyl group. From these data, the structure of $\mathbf{1 0}$ was identical with 2,4-dihyroxy-6-(5,7-dimethyl- 2-oxo-trans-3-trans-5-nonadienyl)-3-methylbenzaldehyde ${ }^{9}$.

\section{Stereochemistry}

The stereochemistry of 6,7 and 8 was examined by CD spectroscopy, coupling constants and NOE experiments. The CD curve (Fig. 4A) and ${ }^{3} J$ values of $8-\mathrm{H} / 8 \mathrm{a}-\mathrm{H}$ and $8 \mathrm{a}-\mathrm{H} / 1-\mathrm{H} \alpha(9.2$ and $10.9 \mathrm{~Hz}$, respectively) of 7 were closely similar to those of 6 , indicating that both 6 and 7 have the same configuration. NOEs were observed between $8-\mathrm{H}$ and $1-\mathrm{H} \alpha$, and $8 \mathrm{a}-\mathrm{H}$ and $1-\mathrm{H} \beta$, respectively. These results indicated that the conformations between $8-\mathrm{H}$ and $8 \mathrm{a}-\mathrm{H}$, and $8 \mathrm{a}-\mathrm{H}$ and $1-\mathrm{H} \alpha$ were diaxial.

The CD curve of 8 was similar to that of 4 (Fig. 4B), so the stereochemistry of 8 was $7 R$ and $13 S^{10}$.

\section{Inhibitory Activities of Azaphilones against gp120-CD4 Binding}

Figure 5 shows the structures of azaphilones which were examined for the inhibition of gp120-CD4 binding

Fig. 3. HMBC correlations of $\mathbf{1 0 .}$

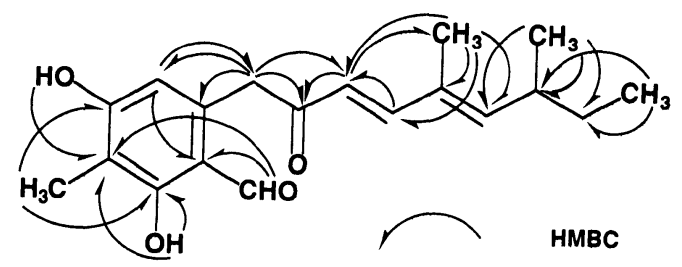

Fig. 4. CD spectra of 6 and 7 (A), and 8 and 4 (B).

(A)

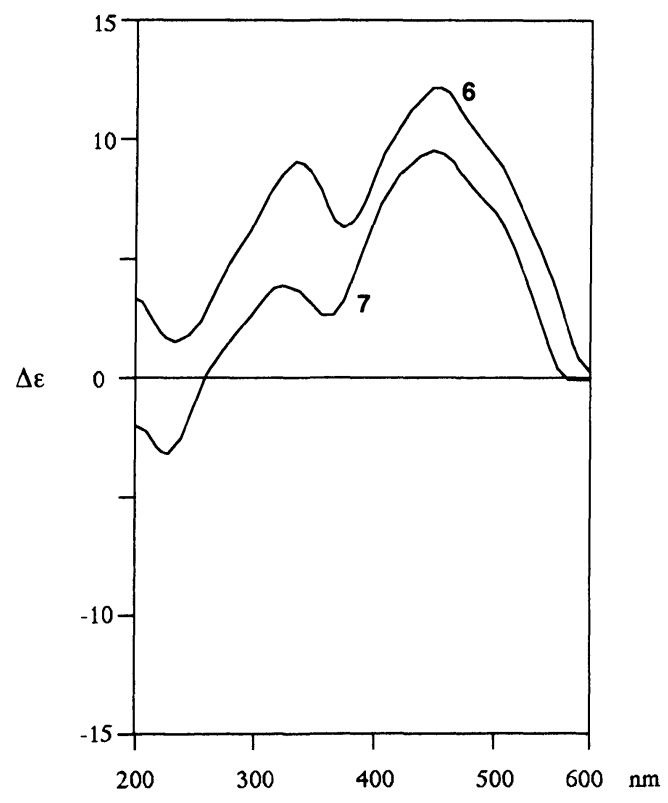

(B)

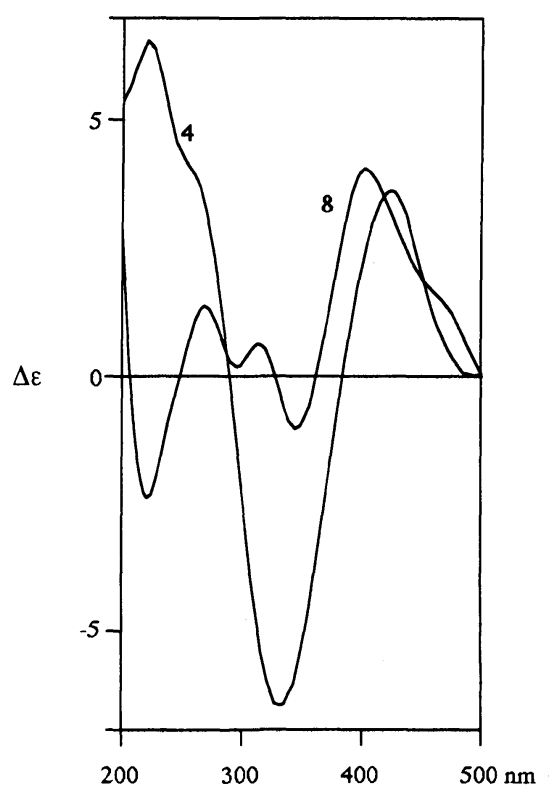


Fig. 5. The structures of azaphilones which were examined by gp120-CD4 binding assay.<smiles>[R]C1=C2C=C(/C=C/C(C)=C/[C@H](C)CC)OC=C2[C@@H]2[C@@H](C(C)=O)C(=O)O[C@]2(C)C1=O</smiles>

Isochromophilone I (1): $\mathrm{R}=\mathrm{Cl}$ Ochrephilone (3): $R=H$<smiles>CC[C@H](C)/C=C(C)/C=C/C1=CC2=C(Cl)C(=O)C3(C)OC(=O)C(C(C)=O)=C3C2=CO1</smiles>

Rubrorotiorin (5)<smiles>CC[C@H](C)/C=C(C)/C=C/C1=CC2=C(Cl)C(=O)[C@](C)(O)[C@H](O)[C@H]2CO1</smiles><smiles>CC[C@H](C)/C=C(C)/C=C/C1=CC2=C(Cl)C(=O)[C@](C)(O)[C@H](CC(C)=O)C2=CO1</smiles>

Isochromophilone II (2)<smiles>CC[C@H](C)/C=C(C)/C=C/C1=CC2=C(Cl)C3=C(C(C)=O)C(=O)O[C@@]3(C)C(=O)C2=CO1</smiles>

Rotiorin (11)<smiles>CC[C@H](C)/C=C/C1=CC2=C(Cl)C(=O)[C@]3(C)OC(=O)C(C(=O)[C@@H](C)O)=C3C2=CO1</smiles>

Chaetoviridin A (16)<smiles>CC[C@H](C)/C=C(C)/C=C/C1=CC2=C(Cl)C(=O)[C@](C)(OC(C)=O)C(=O)C2=CO1</smiles>

Sclerotiorin (4)<smiles>CC[C@H](C)CC(C)CCC1=CC2=C(Cl)C(=O)[C@]3(C)OC(=O)[C@H](C(C)=O)[C@@H]3[C@H]2CO1</smiles>

Tetrahydroisochromophilone (19)<smiles>CC[C@H](C)/C=C(C)/C=C/C1=CC2=C(Cl)C(=O)[C@](C)(O)[C@H](O)C2=CO1</smiles><smiles>CCC(C)/C=C/C1=CC2=C(Cl)C(=O)C3(C)OC(O)(C(C)C(C)O)C(C(=O)O)C3C2=CO1</smiles>

Luteusin A (12)<smiles>CC[C@H](C)/C=C(C)/C=C/C1=CC2=C(Cl)C(=O)[C@](C)(O)[C@H](O)C2=CO1</smiles>

Isochromophilone V (13)<smiles>CC[C@H](C)C[C@@H](C)C(=O)O[C@@]1(C)C(=O)C=C2C=C(/C=C/C(=O)O)OC=C2C1=O</smiles>

Lunatoic acid (18) by the ELISA method. Table 3 shows the $\mathrm{IC}_{50}$ values of azaphilones against gp120-CD4 binding. Among them, the novel 5-bromo-derivative, 9, showed the most potent inhibition with an $\mathrm{IC}_{50}$ value of $2.5 \mu \mathrm{M}$. A monoamine oxidase inhibitor, luteusin A (TL-1, 12) ${ }^{11)}$ and acyl-CoA: cholesterol acyltransferase inhibitors, isochromophilones
V (13), III (14) and IV (15) ${ }^{12)}$ which have a 5-chloro8-hydroxy-6-oxoisochromane skeleton, weakly inhibited the binding, but 8-oxoderivatives, 4 and rotiorin (11), and dechloroderivatives, 3, 6, 7 and 8 , were inactive. $16^{1)}$, $17^{1)}$ and $18^{13)}$ which possess a short side chain at C-3 in the isochromane skeleton, and tetrahydroiso- 
Table 3. Inhibitory activities of azaphilones against gp120-CD4 binding.

\begin{tabular}{lc}
\hline Inhibitor & $\mathrm{IC}_{50}(\mu \mathrm{M})$ \\
\hline Isochromophilone I (1) & 6.6 \\
Isochromophilone II (2) & 3.9 \\
Ochrephilone (3) & 114 \\
Sclerotiorin (4) & $>250$ \\
Rubrorotiorin (5) & $>240$ \\
Dechloroisochromophilone III (6) & $>300$ \\
8-Acetyldechloroisochromophilone III (7) & $>270$ \\
Isorotiorin (8) & $>260$ \\
5-Bromoochrephilone (9) & 2.5 \\
Rotiorin (11) & $>240$ \\
Luteusin A (12) & 9.4 \\
Isochromophilone V (13) & 14.6 \\
Isochromophilone III (14) & 48 \\
Isochromophilone IV (15) & 96 \\
Chaetoviridin A (16) & $>230$ \\
Chaetoviridin B (17) & 140 \\
Lunatoic acid (18) & $>260$ \\
Tetrahydroisochromophilone I (19) & $>260$ \\
\hline
\end{tabular}

chromophilone I (19), were also inactive. These results indicate that the halogen atom at C-5 and the orientation from C-8 to C-1 in the isochromane ring of azaphilones in addition to the diene structure in $\mathrm{C}-3$ side chain are very important for the inhibition of gp 120-CD4 binding.

\section{Discussion}

The previous report that a chlorine atom at C-5 in isochromophilone I is necessary for gp 120-CD4 binding induced an attempt to prepare 5-brominated derivatives $^{2}$. The fermentation of the producing organism in the presence of potassium bromide provided 5bromoochrephilone (9) in addition to the byproducts 6 , 7, 8 and 10. Among 18 azaphilone-related compounds tested for gp120-CD4 binding inhibition, 9 was the strongest inhibitor $\left(\mathrm{IC}_{50}: 2.5 \mu \mathrm{M}\right)$. The above results also indicated that a halogen atom at $\mathrm{C}-5$, a proton at $\mathrm{C}-8$ and a diene structure in $\mathrm{C}-3$ side chain of 6-oxoisochromane ring are necessary for inhibition of gp120CD4 binding.

Azaphilones were well-known to react with amines and to exhibit various biological activities ${ }^{7,12 \sim 17)}$. For example, 4 which is very reactive with amines, strongly inhibits phospholipase A2 ${ }^{17}$. However, it did not inhibit gp120-CD4 binding as shown in Table 3. These facts suggest that the mechanisms of inhibition of gp 120-CD4 binding is not related to the reactivity with amines of gp120 or CD4.
A novel dechloroazaphilone derivative, 7, two known dechloroazaphilone derivatives, $\mathbf{6}$ and $\mathbf{8}$, and an octaketide compound, 10, were also isolated from the culture broth of the isochromophilone producer $P$. multicolor FO-2338 fermented in the presence of potassium bromide. 10 was reported as an intermediate in the total synthesis of $\mathbf{4}^{9)}$. It is considered that $\mathbf{1 0}$ is also an intermediate of the biosynthesis of azaphilone compounds and that the addition of potassium bromide represses the biosynthesis from 10 to $\mathbf{4}$ to provide the above dechloroazaphilones (6, 7 and 8 ), the intermediate 4, and 5-bromoochrephilone (9) as possible shunt products.

\section{Experimental}

General Procedures

The UV spectra were recorded on a Beckman model DU640 spectrophotometer. IR spectra were recorded on a Horiba FT-210 diffraction infrared spectrometer. FAB-MS spectra were obtained with a JEOL model JMS-AX505 HA spectrometer. ${ }^{1} \mathrm{H}-\mathrm{NMR}(270 \mathrm{MHz})$ and ${ }^{13} \mathrm{C}$-NMR $(67.5 \mathrm{MHz})$ spectra were obtained on a JEOL 270-EX spectrometer. Optical rotation and CD spectra were measured with a Jasco DIP-370 polarimeter and a Jasco DIP-370 polarimeter.

\section{Assay for Inhibition of gp120-CD4 Binding}

The inhibitory activities against gp120-CD4 binding were determined by enzyme-linked immunosorbent assay (ELISA) using recombinant soluble CD4 (sCD4) and recombinant gp120 as described previously3).

\section{Fermentation}

The production of azaphilones was carried out using a flask and a jar fermentor, as follows. A loopful of mycelia from a slant culture of $P$. multicolor FO-2338 was transferred to each of twenty 500-ml Erlenmeyer flasks containing $100 \mathrm{ml}$ of a production medium. The flasks were incubated at $27^{\circ} \mathrm{C}$ on a rotary shaker at $200 \mathrm{rpm}$ for 4 days. On the other hand, with a jar fermentor, a loopful of mycelia from a slant culture of P. multicolor FO-2338 was transferred into a $500-\mathrm{ml}$ Erlenmeyer flask containing $100 \mathrm{ml}$ of a seed medium consisting of glucose $2.0 \%$, yeast extract $0.2 \%$, polypeptone $0.3 \%, \mathrm{MgSO}_{4} \cdot 7 \mathrm{H}_{2} \mathrm{O} 0.05 \%, \mathrm{KH}_{2} \mathrm{PO}_{4} 0.1 \%$ and agar $0.1 \%$ (adjusted to $\mathrm{pH} 5.8$ before sterilization). The flask was incubated at $27^{\circ} \mathrm{C}$ on a rotary shaker at $200 \mathrm{rpm}$ for 3 days to provide a seed culture. The seed culture $(400 \mathrm{ml})$ was transferred to a 30 -liter jar 
fermentor containing 20 liters of a production medium. Fermentation was carried out at $27^{\circ} \mathrm{C}$ for 4 days. The production medium consisted of sucrose $2.0 \%$, glucose $1.0 \%$, corn steep powder $1.0 \%$, meat extract $0.5 \%$, yeast extract $0.5 \%, \mathrm{KH}_{2} \mathrm{PO}_{4} 0.1 \%, \mathrm{CaCO}_{3} 0.3 \%, \mathrm{KBr} 3.0 \%$, trace metal solution (containing in $\mathrm{g} /$ liter $\mathrm{FeSO}_{4} \cdot 7 \mathrm{H}_{2} \mathrm{O}$ 1.0, $\mathrm{MnCl}_{2} \cdot 4 \mathrm{H}_{2} \mathrm{O} 1.0, \mathrm{ZnSO}_{4} \cdot 7 \mathrm{H}_{2} \mathrm{O} 1.0, \mathrm{CuSO}_{4} \cdot 5 \mathrm{H}_{2} \mathrm{O}$ $\left.1.0, \mathrm{CoCl}_{2} \cdot 2 \mathrm{H}_{2} \mathrm{O} 1.0\right) 1.0 \%$ and agar $0.3 \%$.

\section{Isolation}

The isolation procedures are summarized in Fig. 1. Azaphilone and related compounds were monitored with their UV absorptions. The culture broths of Erlenmeyer flasks were combined and extracted with equal volume of ethyl acetate, and then filtered. The mycelium residue was reextracted with 1 liters of acetone. The organic solvent layers were combined and concentrated in vacuo to give crude material $(2.1 \mathrm{~g})$. The crude material was dissolved in chloroform and chromatographed on a silica gel column $(4 \times 33 \mathrm{~cm})$ eluted with chloroform and chloroform - methanol $(98: 2,95: 5$ and $90: 10)$ to yield a crude azaphilone fraction. The fraction was subjected to HPLC (ODS-SH, $10 \mathrm{~mm}$ i.d. $\times 250 \mathrm{~mm}$, Senshu Scientific Co., Ltd.; THF-water (43:57); flow-rate, $3.0 \mathrm{ml} /$ minute detection $\mathrm{UV}$ at $330 \mathrm{~nm}$ ), to give three fractions. The first fraction was purified with HPLC (ODS-SH, $10 \mathrm{~mm}$ i.d. $\times 250 \mathrm{~mm}$; acetonitrile - methanol water (45: $7: 48$ ); flow-rate, $3.0 \mathrm{ml} /$ minute; detection UV at $330 \mathrm{~nm})$, to give $6(10.1 \mathrm{mg})$. The second fraction was purified with HPLC (SSC silica gel, $10 \mathrm{~mm}$ i.d. $\times 250 \mathrm{~mm}$, Senshu Scientific Co., Ltd.; $n$-hexane-acetone (5:1); flow-rate, $3.0 \mathrm{ml} /$ minute detection $\mathrm{UV}$ at $330 \mathrm{~nm}$ ), to give $7(3.0 \mathrm{mg})$ and $3(24.7 \mathrm{mg})$. The third fraction was crystallized with chloroform to give $\mathbf{1 0}(3.0 \mathrm{mg})$. On the other hand, 20 liters of cultured broth of $P$. multicolor FO-2338 in a 30-liter jar fermentor was extracted with 18 liters of ethyl acetate. The organic layer was concentrated in vacuo to give crude material (32 g). It was dissolved in chloroform and chromatographed on a silica gel column $(7 \times 20 \mathrm{~cm})$ eluted with chloroform and chloroform-methanol $(98: 2)$ to yield fractions 1 $(3.10 \mathrm{~g})$ and $2(8.57 \mathrm{~g})$. Fraction 2 was recrystallized in dichloromethane to give $10(2.25 \mathrm{~g})$. The mother liquor and Fraction 1 were combined and rechromatographed on a silica gel column, eluted with dichloromethaneethanol $(98: 2)$ to give crude azaphilone fraction $(2.77 \mathrm{~g})$ and 3 (174 $\mathrm{mg})$. The crude azaphilone fraction was chromatographed on a Toyopearl HW-40 eluted with chloroform - methanol (1:1), a silica gel column $(2.8 \times$ $21 \mathrm{~cm}$ ) eluted with chloroform - methanol (98:2). Final- ly, $8(12.5 \mathrm{mg})$ and $9(3.0 \mathrm{mg})$ were obtained after purification by HPLC (ODS-SH, $10 \mathrm{~mm}$ i.d. $\times 250 \mathrm{~mm}$; THF - water ( $45: 57$ ); flow-rate, $3.0 \mathrm{ml} /$ minute detection UV at $330 \mathrm{~nm}$, and SSC silica gel, $10 \mathrm{~mm}$ i.d. $\times 250 \mathrm{~mm}$; $n$-hexane - acetone $(8: 1)$; flow-rate, $3.0 \mathrm{ml} / \mathrm{minute}$ detection UV at $330 \mathrm{~nm}$ ).

Dechloroisochromophilone III (6): Yellow powder; $[\alpha]_{\mathrm{D}}^{23}-298^{\circ}$ (c 0.1, EtOH), EI-MS, $m / z 318(\mathrm{M})^{+}$; FAB-MS, $m / z 319(\mathrm{M}+\mathrm{H})^{+}$; HR-FAB-MS, found 319.1892, calcd. 319.1909 for $\mathrm{C}_{19} \mathrm{H}_{27} \mathrm{O}_{4}$; Molecular formula, $\mathrm{C}_{19} \mathrm{H}_{26} \mathrm{O}_{4}$; UV $\lambda_{\max }^{\mathrm{CH}_{3} \mathrm{OH}} \mathrm{nm}(\varepsilon), 265(5,500)$, and 374 (20,700); IR $v_{\max }^{\mathrm{KBr}} \mathrm{cm}^{-1}, 3430(\mathrm{O}-\mathrm{H}), 2960(\mathrm{C}-\mathrm{H})$, $2925(\mathrm{C}-\mathrm{H}), 1645(\mathrm{C}=\mathrm{O})$, and $1580(\mathrm{C}=\mathrm{C})$; ${ }^{1} \mathrm{H}-$ and ${ }^{13} \mathrm{C}-\mathrm{NMR}\left(\mathrm{CDCl}_{3}\right)$, see Table 1 .

Dechloroisochromophilone IV (7): Yellow powder; $[\alpha]_{\mathrm{D}}^{23}-260^{\circ}$ (c 0.1 , EtOH); EI-MS, $m / z 360(\mathrm{M})^{+}$; FAB-MS, $m / z 361(\mathrm{M}+\mathrm{H})^{+}$; HR-EI-MS, found 360.1947 , calcd. 360.1937 for $\mathrm{C}_{21} \mathrm{H}_{28} \mathrm{O}_{5}$; UV $\lambda_{\max }^{\mathrm{CH}_{3} \mathrm{OH}} \mathrm{nm}$ (E), 246 (5,100); and 372 (21,300); IR $v_{\max }^{\mathrm{KBr}} \mathrm{cm}^{-1}, 3440$ $(\mathrm{O}-\mathrm{H}), 2965(\mathrm{C}-\mathrm{H}), 2930(\mathrm{C}-\mathrm{H}), 1740(\mathrm{C}=\mathrm{O}), 1630$ $(\mathrm{C}=\mathrm{O})$, and $1580(\mathrm{C}=\mathrm{C}) ;{ }^{1} \mathrm{H}-\mathrm{NMR}\left(\mathrm{CDCl}_{3}\right)$, see Table 1 .

Isorotiorin (8): Red powder; $[\alpha]_{\mathrm{D}}^{23}+458^{\circ}$ (c 0.1 , EtOH); FAB-MS, $m / z 381(\mathrm{M}+\mathrm{H})^{+}$; HR-EI-MS, found 381.1718, calcd. 381.1702 for $\mathrm{C}_{23} \mathrm{H}_{24} \mathrm{O}_{5}$; UV $\lambda_{\max }^{\mathrm{CH}_{3} \mathrm{OH}} \mathrm{nm}$ (ع), 282 (11,100); $416(13,800)$, and 557 (2,930); IR $v_{\max }^{\mathrm{KBr}}$ $\mathrm{cm}^{-1}, 2960(\mathrm{C}-\mathrm{H}), 2925(\mathrm{C}-\mathrm{H}), 1765(\mathrm{C}=\mathrm{O}), 1685$ $(\mathrm{C}=\mathrm{O}), 1635(\mathrm{C}=\mathrm{O}), 1620(\mathrm{C}=\mathrm{C})$, and $1530(\mathrm{C}=\mathrm{C})$; ${ }^{1} \mathrm{H}$ - and ${ }^{13} \mathrm{C}$-NMR $\left(\mathrm{CDCl}_{3}\right)$, see Table 2 .

5-Bromoochrephilone (9): Yellow powder; $[\alpha]_{\mathrm{D}}^{23}$ $+152^{\circ}$ (c 0.05, EtOH); FAB-MS, $m / z 461(\mathrm{M}+\mathrm{H})^{+}$; HR-FAB-MS, found 461.0976, calcd. 461.0964 for $\mathrm{C}_{23} \mathrm{H}_{26} \mathrm{O}_{5}{ }^{79} \mathrm{Br}$; Molecular formula, $\mathrm{C}_{23} \mathrm{H}_{25} \mathrm{O}_{5} \mathrm{Br}$; UV $\lambda_{\max }^{\mathrm{CH}_{3} \mathrm{OH}} \mathrm{nm}(\varepsilon), 257$ (13,400), 273 (12,600), $335(9,400)$, $358(10,400)$, and $412(11,000) ;$ IR $v_{\max }^{\mathrm{KBr}} \mathrm{cm}^{-1}, 2965$ $(\mathrm{C}-\mathrm{H}), 1780(\mathrm{C}=\mathrm{O}), 1720(\mathrm{C}=\mathrm{O}), 1630(\mathrm{C}=\mathrm{O})$, and 1560 $(\mathrm{C}=\mathrm{C}) ;{ }^{1} \mathrm{H}-\mathrm{NMR}\left(\mathrm{CDCl}_{3}\right)$, see Table 2 .

2,4-Dihyroxy-6-(5,7-dimethyl-2-oxo-trans-3-trans-5nonadienyl)-3-methylbenzaldehyde (10): Colorless needles; $[\alpha]_{\mathrm{D}}^{23}+51^{\circ}$ (c 1.0, $\mathrm{CHCl}_{3}$ ); FAB-MS, $m / z 317$ $(\mathrm{M}+\mathrm{H})^{+}$; HR-EI-MS, found 316.1680, calcd. 316.1675 for $\mathrm{C}_{19} \mathrm{H}_{25} \mathrm{O}_{4}$; Molecular formula, $\mathrm{C}_{19} \mathrm{H}_{24} \mathrm{O}_{4}$; UV $\lambda_{\max }^{\mathrm{CH}_{3} \mathrm{OH}} \mathrm{nm}(\varepsilon), 290$ (45,200); IR $v_{\max }^{\mathrm{KBr}} \mathrm{cm}^{-1}, 3460(\mathrm{O}-\mathrm{H})$, $2965(\mathrm{C}-\mathrm{H}), 2925(\mathrm{C}-\mathrm{H}), 1680(\mathrm{C}=\mathrm{O}), 1625(\mathrm{C}=\mathrm{O}), 1595$ $(\mathrm{C}=\mathrm{C})$, and $1580(\mathrm{C}=\mathrm{C}) ;{ }^{1} \mathrm{H}-\mathrm{NMR}\left(\delta=\mathrm{ppm}\right.$ in $\left.\mathrm{CDCl}_{3}\right)$, $12.64(1 \mathrm{H} \mathrm{s}, 2-\mathrm{OH}), 9.85(1 \mathrm{H} \mathrm{s}, 1-\mathrm{CHO}), 7.34(1 \mathrm{H} \mathrm{d}$ $\left.J=15.7 \mathrm{~Hz}, 4^{\prime}-\mathrm{H}\right), 6.55(1 \mathrm{H} \mathrm{s}, 4-\mathrm{OH}), 6.18(1 \mathrm{H} \mathrm{d}$ $\left.J=15.7 \mathrm{~Hz}, 3^{\prime}-\mathrm{H}\right), 6.16(1 \mathrm{H} \mathrm{s}, 5-\mathrm{H}), 5.57(1 \mathrm{H} \mathrm{d} J=9.9 \mathrm{~Hz}$, $\left.6^{\prime}-\mathrm{H}\right), 4.07$ (2H s, 1'-H), 2.48 (1H m, 7'-H), 2.05 (3H s, $\left.3-\mathrm{CH}_{3}\right), 1.79\left(3 \mathrm{H} \mathrm{s}, 5^{\prime}-\mathrm{CH}_{3}\right), 1.40\left(2 \mathrm{H} \mathrm{m}, 8^{\prime}-\mathrm{H}\right), 1.00(3 \mathrm{H}$ d $\left.J=6.6 \mathrm{~Hz}, 7^{\prime}-\mathrm{CH}_{3}\right), 0.85\left(3 \mathrm{H} \mathrm{t}, J=7.2 \mathrm{~Hz}, 9^{\prime}-\mathrm{H}\right)$; 
${ }^{13} \mathrm{C}-\mathrm{NMR}\left(\delta=\mathrm{ppm}\right.$ in $\left.\mathrm{CDCl}_{3}\right), 197.2\left(\mathrm{~s}, \mathrm{C}-2^{\prime}\right), 192.5(\mathrm{~d}$, 1-CHO), 164.3 (s, C-2), 161.3 (s, C-4), 151.9 (d, C-4'), 151.8 (d, C-6'), 137.3 (s, C-6), 131.8, (s, C-5'), 122.4 (s, C-3'), 112.9 (s, C-3), 111.1 (d, C-5), 110.6 (s, C-1), 43.7 $\left(\mathrm{t}, \mathrm{C}-1^{\prime}\right), 35.2\left(\mathrm{~d}, \mathrm{C}-7^{\prime}\right), 29.8\left(\mathrm{t}, \mathrm{C}-8^{\prime}\right), 12.4\left(\mathrm{q}, 5^{\prime}-\mathrm{CH}_{3}\right)$, $12.4\left(\mathrm{q}, 7^{\prime}-\mathrm{CH}_{3}\right), 11.9\left(\mathrm{q}, \mathrm{C}-9^{\prime}\right), 6.9\left(\mathrm{q}, 3-\mathrm{CH}_{3}\right)$.

\section{Reduction of 1}

$1(13.14 \mathrm{mg})$ was dissolved in $10 \mathrm{ml}$ of ethanol and treated with $5 \% \mathrm{Pd}-\mathrm{C}(15 \mathrm{mg})$ under hydrogen gas at room temperature for 40 minutes. The reaction mixture was filtered, and the filtrate was evaporated to dryness. The residue was dissolved in dichloromethane and chromatographed on a silica gel column $(1.2 \times 8.0 \mathrm{~cm})$ using chloroform-methanol $(49: 1)$ as the developing solvent. Finally, 9, 10, 11, 12-tetrahydroisochromophilone $(19,5.32 \mathrm{mg})$ was obtained by HPLC [column: SSC Silica gel, $10 \mathrm{~mm}$ i.d. $\times 250 \mathrm{~mm}$, mobile phase: $n$-hexane acetone $(9: 1)$, flow-rate: $3.0 \mathrm{ml} /$ minute, detection: UV at $330 \mathrm{~nm}$ ].

9, 10, 11, 12-Tetrahydroisochromophilone (19): Colorless powder; FAB-MS, $m / z \quad 421(\mathrm{M}+\mathrm{H})^{+}$; HRFAB-MS, found 421.1778, calcd. 421.1738 for $\mathrm{C}_{23} \mathrm{H}_{30} \mathrm{O}_{5} \mathrm{Cl}$; ${ }^{1} \mathrm{H}-\mathrm{NMR}\left(270 \mathrm{MHz}, \delta\right.$ in $\left.\mathrm{CDCl}_{3}\right), 7.45$ $(1 \mathrm{H}, \mathrm{s}, 1-\mathrm{H}), 6.48(1 \mathrm{H} \mathrm{s}, 3-\mathrm{H}), 3.78(1 \mathrm{H}, \mathrm{d}, J=12.2 \mathrm{~Hz}$, $\left.3^{\prime}-\mathrm{H}\right), 3.70(1 \mathrm{H}, \mathrm{d}, J=12.2 \mathrm{~Hz}, 8-\mathrm{H}), 2.46\left(3 \mathrm{H}, \mathrm{s}, 5^{\prime}-\mathrm{H}\right)$, $1.59\left(3 \mathrm{H}, \mathrm{s}, 7-\mathrm{CH}_{3}\right), 0.98\left(3 \mathrm{H}, \mathrm{d}, 11-\mathrm{CH}_{3}\right), 0.90(3 \mathrm{H}, \mathrm{d}$, $\left.13-\mathrm{CH}_{3}\right), 0.83(3 \mathrm{H}, \mathrm{t}, J=7.4 \mathrm{~Hz}, 15-\mathrm{H})$.

\section{Acknowledgments}

We thank Prof. M. Yamazaki (Chiba University) for providing a sample of luteusin A (TL-1), Dr. K. Koyama (Meiji College of Pharmacy) for providing samples of chaetoviridins A and B, and Dr. M. Natsume (Tokyo University of Agriculture and Technology) for providing samples of lunatoic acid, rubrorotiorin, ochrephilone and sclerotiorin. This work was supported by a Grant-in-Aids from the Ministry of Education, Science and Culture of Japan (No. 06772076) and the Japan Society for the Promotion of Science (JSPS-RFTF 9610034), and Kitasato University Research Grant for Young Researchers.

\section{References}

1) TAKahashi, M.; K. Koyama \& S. Natori: Four new azaphilones from Chaetomium globosum var. flavoviridae. Chem. Pharm. Bull. 38: 625 628, 1990

2) Ömura, S.; H. Tanaka, K. Matsuzaki, H. Ikeda \& R. Masuma: Isochromophilones I and II, novel inhibitors against gp120-CD4 binding from Penicillium sp. J. Antibiotics 46: 1908 1911, 1993

3) Matsuzaki, K.; H. Ikeda, H. Tanaka, R. Masuma \& S. ÖMURA: Isochromophilones I and II, novel inhibitors against gp120-CD4 binding produced by Penicillium multicolor FO-2338. I. Screening, taxonomy, fermenta- tion, isolation and biological activity. J. Antibiotics 48: $703 \sim 707,1995$

4) MatsuZaKi, K.; S. ŌMURA \& H. TANaKa: Isochromophilones I and II, novel inhibitors against gp 120-CD4 binding produced by Penicillium multicolor FO-2338. II. Structure elucidation. J. Antibiotics 48: 708 713, 1995

5) Seto, H. \& M. TANABE: Utilization of ${ }^{13} \mathrm{C}-{ }^{13} \mathrm{C}$ coupling in structural and biosynthetic studies. III. Ochrephilone-a new fungal metabolite. Tetrahedron Lett. $651 \sim 654,1974$

6) Curtin, T. P. \& J. Reilly: Sclerotiorine, $\mathrm{C}_{20} \mathrm{H}_{20} \mathrm{O}_{5} \mathrm{Cl}$, a chlorine-containing metabolic product of Penicillium sclerotiorum Van Beyma. Biochem. J. 34: 1419 1421, 1940

7) Pairet, L.; S. K. Wrigley, I. Chetland, E. E. Reynolds, M. A. Hyes, J. Holloway, A. M. Ainsworth, W. Katzer, X.-M. Cheng, D. J. Hupe, P. Charlton \& A. M. DOHERTY: Azaphilones with endothelin receptor binding activity produced by Penicillium sclerotiorum: Taxonomy, fermentation, isolation, structure elucidation and biological activity. J. Antibiotics 48: 913 923, 1995

8) Chong, R.; R. R. KInG \& W. B. Whalley: The synthesis of sclerotiorin and of an analogue of rotiorin. J. Chem. Soc. Chem. Commun. 1512 1513, 1969

9) Chong, R.; R. R. KING \& W. B. Whalley: The chemistry of fungi. Part LXI. The synthesis of $( \pm)$-sclerotiorin, of ( \pm )-4,6-dimethylocta-trans-2, trans-4-dienoic acid, and an analogue of rotiorin. J. Chem. Soc. (C) $3566 \sim 3571$, 1971

10) Steyn, P. S. \& R. VleggaAR: The structure of dihydroxy-8-epi-austdiol and the absolute configuration of the azaphilones. J. Chem. Soc. Perkin I, $204 \sim 206,1976$

11) Fujimoto, H.; T. Matsudo, A. Yamaguchi \& $\mathbf{M}$. YAMAZAKI: Two new fungal azaphilones from Talaromyces luteus, with monoamine oxidase inhibitory effect. Heterocycles 30: 607 616, 1990

12) Arai, N.; K. Shiomi, H. Tomoda, N. Tabata, D.-J. YANG, R. Masuma, T. KaWaKubo \& S. Ōmura: Isochromophilones III $\sim$ VI, inhibitors of acyl-CoA: cholesterol acyltransferase produced by Penicillium multicolor FO3216. J. Antibiotics 48: 696 702, 1995

13) Natsume, M.; Y. TaKahashi \& S. Marumo: Chlamydospore-like cell-inducing substances of fungi: Close correlation between chemical reactivity with methylamine and biological activity. Agric. Biol. Chem. 52: $307 \sim 312$, 1988

14) SATOH, Y. \& M. YamaZaKI: Studies on the monoamine oxidase (MAO) inhibitory potency of TL-1, isolated from a fungus, Talaromyces luteus. Chem. Pharm. Bull. 37: $206 \sim 207,1989$

15) Yoshida, E.; H. FuJimoto \& M. YAmazaKI: Isolation of three new azaphilones, luteusins $\mathrm{C}, \mathrm{D}$, and $\mathrm{E}$, from as ascomycete, Talaromyces luteus. Chem. Pharm. Bull. 44: 284 287, 1996

16) Yasukawa, K.; M. TaKahashi, S. Natori, K. Kawai, M. YamazaKi, M. TakeUChI \& M. TaKido: Azaphilones inhibit tumor promotion by $12-O$-tetradecanoylphorbol13-acetate in two-stage carcinogenesis in mice. Oncology 51: $108 \sim 112,1994$

17) Nakamura, K.; T. Kino, K. Niko, S. Kyotoo \& M. OKUHARA: Phospholipase $\mathbf{A}_{2}$ inhibitors containing sclerotiorin from Penicillium sclerotiorum for treatment of inflammatory pancreatitis, and allergy. JP 02255615 A2, October 16, 1990 